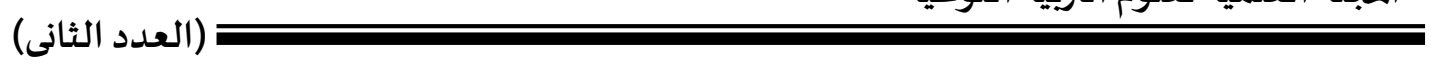

\title{
Nutritional Therapeutic Studies on Albino Rats Inflicted with Hypercholesterolemia
}

\author{
Fatma EL-Zahraa Amin EL-Sherif, Mohamed Mostafa El-Sayed Ali and Eman \\ Mahmoud Nabhan
}

Nutrition and Food Science Dept., Faculty of Home Economics, Menoufia University, Egypt

\begin{abstract}
$\underline{\text { Abstract }}$
This work was conducted to study the effect of Jojoba oil, lavender oil and their mixture on hypercholesterolemic rats. Thirty five male albino rats, weighing $(150 \pm 10 \mathrm{~g})$, were divided into 7 groups (5 rats each), 25 of them fed on $1.5 \%$ cholesterol $+0.2 \%$ bile salts to induce hypercholesterolemia The first main group fed on basal diet as a negative control group. One of the second hypercholesterolemic main group (5 rats) fed on basal diet as apositive control group , and the other hypercholesterolemic rats fed on basal diet and treated by Jojoba oil, lavender oil $(2.5 \%$ and $5 \%$ ) and mixture of them $2.5 \%$ for 4 weeks. At the end of the experiment serum samples were analyzed for the following parameters: Lipid profile; total cholesterol (T.C), total bilirubin, tri-glycerides (T.G), high density lipoprotein (HDLc), low density lipoprotein (LDLc), very low density lipoprotein (VLDLc) ; urea , creatinine, uric acid ; glutamic oxaloacetic transaminase (GOT), glutamic pyruvic transaminase (GPT), alkaline phosphatase (ALP) and glucose. At the same time, the organs: Heart, kidney, liver, lungs and spleen were removed for weghting. The results indicated that treating rats with Jojoba oil, lavender oil and mixture of them decreased serum glucose, creatinine, uric acid, ALT, AST and ALP, as compared to the positive control group. It was concluded that the diet of Jojoba oil, lavender oil and mixture of them led to a significant decrease in lipid fractions ; (T.C),(T.G),(LDLc),(VLDLc) With increase of (HDL), and these treatment are recommended to reduce the level of lipid profile for the patients with hypercholesterolemia.
\end{abstract}

Key words: Jojoba oil, lavender oil, hypercholesterolemic rats, weight of internal organs. 
در اسات تغذية علاجية علي الفئران البيضاء المصابة بارتفاع الكولسترول

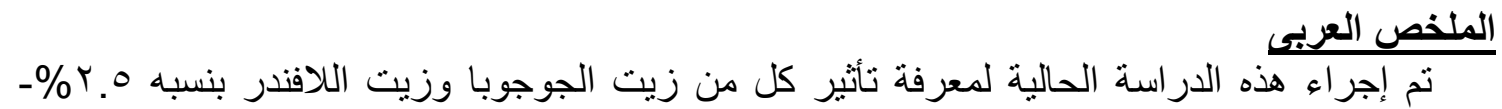

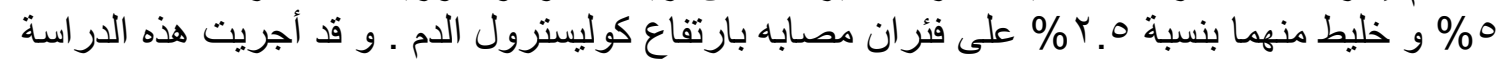

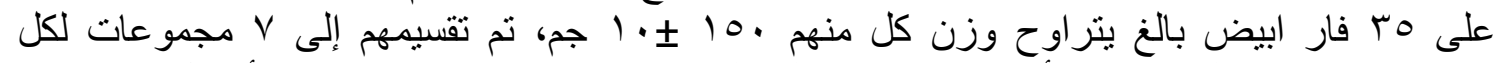

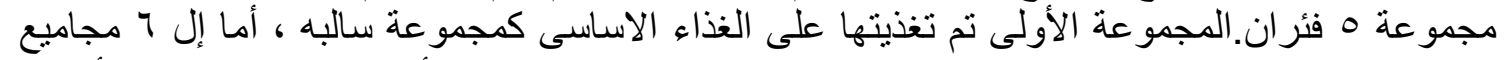

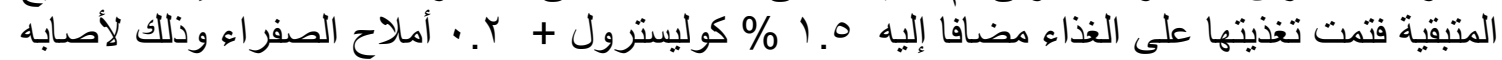

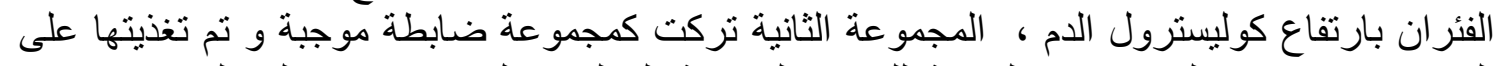

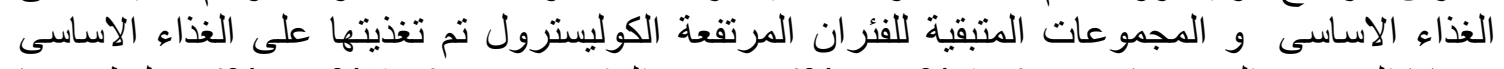

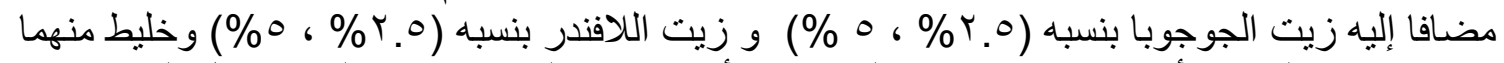

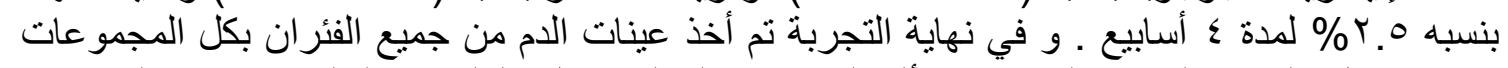

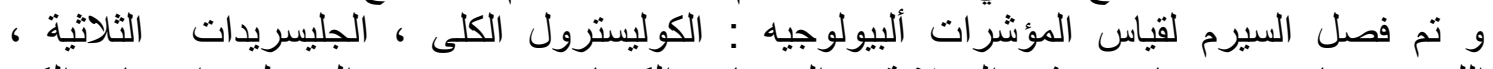

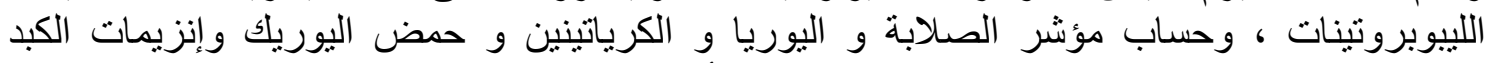
(ALT,AST, ALP)

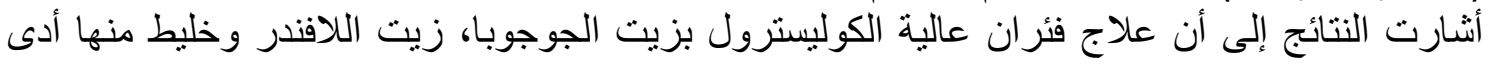

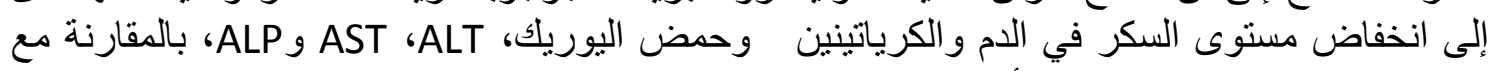

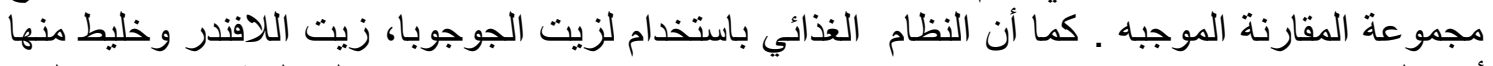

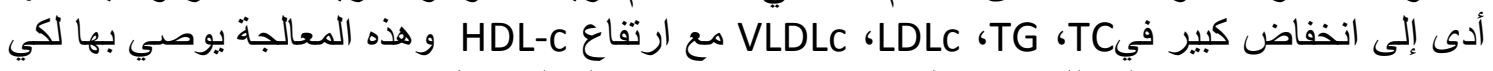
ينخفض، مستوى دهون الام للمرضى الذين الذين يعانون من ارتفاع الكولسترول.

الكلمات المفتاحية: ارتفاع الكوليسترول، الجوجوبا ، اللافندر ، التغيرات في وزن الكبد و الكليتين والقلب

و الطحال 


\section{Introduction}

Cholesterol is a waxy lipid soluble compound found only in animal tissues. It is a member of a group of compounds called sterols, being an integral component of every cell in the body. It facilitates the absorption and transport of fatty acids. Cholesterol acts as the precursor for the synthesis of various steroid hormones, including cortisol, cortisone, and aldosterone in the adrenal glands, and of the sex hormones: Progesterone, estrogen, and testosterone. Cholesterol sometimes precipitates along with other compounds in the gallbladder to form gallstones. Cholesterol is found in food of animal origin and is continuously synthesized in the body, primarily in the liver. Increased levels of low-density lipoprotein cholesterol may be associated with the pathogenesis of atherosclerosis, while levels of high-density lipoprotein cholesterol appear to lower the person's risk for heart disease. Normal adult levels of blood cholesterol are 150 to $200 \mathrm{mg} / \mathrm{dl}$ or 3.9 to $5.2 \mathrm{mmol} / \mathrm{L}$ (Sl units).It is also called cholesterin (Whitney and Rolfes, 1993).

Lavender essential oil (LEO) is one the most favorite and widely used essential oils in aromatherapy. Many studies have demonstrated its functions in calming, assisting sleep, reducing pain and muscular spasms and its antiseptic function (Huang et al. 2012). Folk and traditional therapeutic use of the essential oil of English lavender for pain, infection, relaxation, and sedation, dates back centuries (Denner, 2009). Lavender essential oil has been used as an anxiolytic drug, a mood stabilizer, a sedative, spasmolytic, antihypertensive, antimicrobial, analgesic agent (Sasannejad et al. 2012).

Jojoba has anti-inflammatory effect and it can be used on a variety of skin conditions including skin infections, skin aging, as well as wound healing. Moreover, jojoba has been shown to play a role in cosmetics formulas such as sunscreens and moisturizers, and also enhances the absorption of topical drugs (Pazyar et al. 2013).

Cholesterol lowering foods should be incorporated into everyone's diet for optional health. The percentages by which these foods lower cholesterol is essential to people who have high levels of cholesterol greater than $200 \mathrm{mg} / \mathrm{dl}$, and have been diagnosed with hypercholesterolemia. Different diet, lifestyles, and foods will work differently for different people.

\section{Materials and Methods}

\section{Materials}

Jojoba oil and lavender oil, obtained from spices shop in Cairo. Casein, vitamins, minerals, cholesterol and bile salts were purchased from El- Gomoria Company Cairo, Egypt. Male albino rats weighing $150 \pm 10 \mathrm{~g}$ obtained from Medical Insects Research Institute, Dokki, Cairo.

\section{Methods:}

\section{Preparation of basal diet :}

Basal diet composition of tested rats consisted of casein $10 \%$, corn oil $10 \%$, chorine chloride $0.25 \%$, vitamins mixture (1\%), cellulose (5\%), salt mixture (4\%), corn starch (up to 100\%) according to Reeves et al. (1993) . 


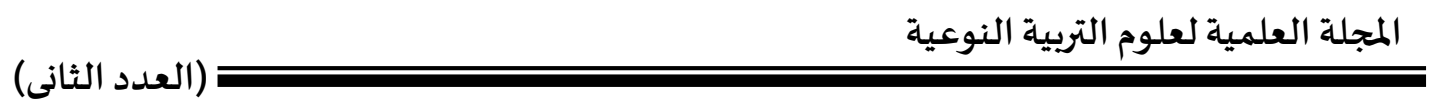

The composition of salt and vitamins mixtures were that of Hegested $\boldsymbol{e t}$ al. (1941) and Campbell (1963). .

\section{Preparation of hypercholesterolemic rats :}

Thirty five (35) male rats ( Spargue - Dawley strain ) weighing $150 \pm 10$ $\mathrm{gm}$ were fed on hypercholesterolemic diet which is the basal diet with addition of $1.5 \%$ cholesterol $+0.2 \%$ bile salts for feeding rats 3 weeks before starting the experiment to induce hypercholesterolemia. All the period of the experiment, the inflicted rats consumed $1.5 \%$ cholesterol + bile salts $0.2 \%$. (Hegsted et al. 1941) Experimental Designs:

All biological experiments were done in the Faculty of Home Economics, Menoufia University, Shebin EL- Kom .Rats were housed in wire cages at a room temperature $25^{\circ} \mathrm{C}$ and kept under normal healthy conditions.

The rats were divided into 7 groups ( 5 rats each).The groups of rats were as follows:

Group (1) (-ve): 5 healthy rats, fed on basal diet only, as a negative control.

Group (2): Hypercholesterolemic rats were fed on the basal diet only as control+ve).

Group (3): Hypercholesterolemic rats were fed on basal diet containing 2.5\% of Jojoba oil for 28 days.

Group (4): Hypercholesterolemic rats were fed on basal diet containing 5\% of Jojoba oil for 28 days.

Group (5): Hypercholesterolemic rats were fed on basal diet containing 2.5\% of lavender oil for 28 days.

Group (6): Hypercholesterolemic rats were fed on basal diet containing 5\% of lavender oil for 28 days.

Group (7): Hypercholesterolemic rats were fed on basal diet with $2.5 \%$ of formula which formed of Jojoba oil and lavender oil mixture for 28 days.

Each of the above group was kept in signle cage. The diets were introduced to rats in special non-scattering feeding cups to avoid loss of feed and contamination. Tap water provided to rats by means of glass tubes projecting through wire cages from inverted bottles supported to one side of the cage. Rats were weighted at the beginning of the experiment then weekly and at the end of the experiment.

\section{Biological evaluation:}

Biological evaluation of the different diets was carried out by determination of feed daily intake and body weight gain every week. The body weight gain $\mathrm{g}$ (BWG g/day), relative internal organs weights and feed efficiency ratio (FER) were calculated according to Chapman et al. (1959) using the following equations:

Body Weight Gain $($ BWG $)=$ Final weight $(\mathrm{g})-$ Initial Weight $(\mathrm{g})$

Feed efficinency ratio $($ FER $)=$ Gain in body weight $(\mathrm{g}) /$ Feed intake $(\mathrm{g})$. 


\section{Blood sample and organs collection:}

From all the previously mentioned groups, blood samples collected after 12 hours fasting at the end of experiment. Using the retro-orbital method, by means of a microcapillary glass, blood was collected into a dry clean centrifiuge tube, and left to clot at room temperature for half an hours. The blood was centrifuged for 10 minutes at 3000 r.p.m to separate the serum. Serum was carefully aspirated and transferred into clean quit fit plastic tubes and kept frozen at $-20^{\circ} \mathrm{C}$ until the time of analysis . The organs (liver, kidney, heart, lungs and spleen) were removed, washed in saline solution and weighed

\section{Biochemical analysis:}

Glucose (mg/dl) was estimated according to the method described by (Trinder, 1969). Assessment of trighcrides was carried out according to Fossati and Prencipe (1982) . The priniciple used of total cholesterol determination was according to Allian (1979), and HDL fraction in the supernatant determined by the same method used for total cholesterol, according to Lopez (1977). The calculation of serum VLDL (very low density lipoprotein) and LDL carried out according to the method of Lee and Nieman (1996). GPT (ALT) was assessed according to the method of Henry (1974) and Yound (1975) .GOT was determined according to the method of Henry (1974) and Yound (1975). Alkaline Phosphatase (ALP): Kits were obtained from Biosystems S.A.Kits, Barcelona (Spain). Serum ALP was determined according to IFCC methods(1983). Serum uric acid was determined in the serum according to the method described by Barham and Trinder (1972) and Fossati et al. (1980). Urea was determined in the serum according to the method described by Patton and Crouch (1977). Creatinine also determined from colored complex when reacts with alkaline picrate. This reaction described by Faulkner and King (1976).

\section{Statical analysis:}

The data were statically analysed using a computerized costat program by one way ANOVA. The results are presented as mean \pm SD . Differences between treatments at $\mathrm{p} \leq 0.05$ were considered significant (Armitage and Berry, 1987).

\section{Results and Discussion}

1- Effect of Jojoba oil, lavender oil and mixture of bothl oils on body weight gain (BWG), feed intake (FI) and feed efficiency ratio (FER) of hypercholesterolemic rats.

Data of Table (1) revealed that hypercholesterolemia lowered pronouncedly the BWG of rats. Control (-) rats revealed $+12.82 \%$ increase compared to that of hypercholesterolemia group. This occurred regardless of remarkable increase of FI (from355.50 \pm 2.5 to $360.12 \pm 1.82 \mathrm{~g}$ per day).

Considerable losses in BWG and FER by hypercholesterolemia were evidently corrected by feeding on basal diets contained of Jojoba oil, lavender oil or their mixture. It is clear that maximum increase of BWG recorded for 5\% 
Jojoba oil group (G4).This group revealed also more appetite and relatively high FI. At the same time highest FER was found for 5\% of lavender oil (G6).

Table (1): Effect of Jojoba oil, lavender oil, mixture of both oils on body weight gain (g), feed intake (FI) and feed efficiency ratio (FER) of hypercholesterolemic rats.

\begin{tabular}{|c|c|c|c|c|c|c|}
\hline $\begin{array}{l}\text { Parameter } \\
\text { Groups }\end{array}$ & $\begin{array}{c}\text { BWG } \\
\text { ( g/28 day) } \\
\text { (Mean } \pm \text { SD) }\end{array}$ & $\begin{array}{l}\text { \% Change } \\
\text { of Control } \\
\text { (+) group }\end{array}$ & $\begin{array}{c}\text { FI ( g/28 day }) \\
(\text { Mean } \pm \text { SD })\end{array}$ & $\begin{array}{c}\text { \% Change of } \\
\text { Control (+) } \\
\text { group }\end{array}$ & $\begin{array}{c}\text { FER } \\
(\text { Mean } \pm \text { SD })\end{array}$ & $\begin{array}{l}\% \text { Change of } \\
\text { Control (+) } \\
\text { group }\end{array}$ \\
\hline $\begin{array}{l}\text { Control-ve } \\
\text { (G1) }\end{array}$ & $66.00 \pm 1.00 \mathbf{b}$ & +12.82 & $355.50 \pm 2.5 \mathrm{~g}$ & -1.28 & $0.19 \pm 0.01 \mathbf{a}$ & +18.75 \\
\hline $\begin{array}{l}\text { Control+ve } \\
\text { (G2) }\end{array}$ & $58.50 \pm 1.50 \mathbf{c}$ & 0.00 & $360.12 \pm 1.82 \mathbf{f}$ & 0.00 & $0.16 \pm 0.02 \mathbf{a}$ & 0.00 \\
\hline \begin{tabular}{|l|}
$\begin{array}{l}\text { Jojoba oil } \\
(2.5 \%)(G 3)\end{array}$ \\
\end{tabular} & $63.70 \pm 1.47 \mathbf{b}$ & +8.88 & $380.22 \pm 2.03 \mathbf{e}$ & +5.58 & $0.17 \pm 0.02 \mathbf{a}$ & +6.25 \\
\hline \begin{tabular}{|l|}
$\begin{array}{l}\text { Jojoba oil (5\%) } \\
\text { (G4) }\end{array}$ \\
\end{tabular} & $73.92 \pm 1.02 \mathbf{a}$ & +26.36 & $410.61 \pm 1.98 \mathbf{c}$ & +14.02 & $0.18 \pm 0.02 \mathbf{a}$ & +12.50 \\
\hline \begin{tabular}{|l} 
Lavender oil \\
$(2.5 \%)$ (G5)
\end{tabular} & $59.62 \pm 1.51 \mathrm{c}$ & +1.91 & $425.86 \pm 2.57 \mathbf{b}$ & +18.25 & $0.14 \pm 0.02 \mathbf{a}$ & -12.50 \\
\hline $\begin{array}{l}\text { Lavender oil } \\
(5 \%)(\text { G6) }\end{array}$ & $64.18 \pm 1.74 \mathbf{b}$ & +9.71 & $430.15 \pm 1.78 \mathbf{a}$ & +19.44 & $0.15 \pm 0.02 \mathbf{a}$ & -6.25 \\
\hline \begin{tabular}{|l|} 
Mixture of \\
both oils $2.5 \%$ \\
(G7) \\
\end{tabular} & $60.64 \pm 2.11 \mathbf{c}$ & +3.66 & $400.04 \pm 2.00 \mathrm{~d}$ & +11.08 & $0.15 \pm 0.02 \mathbf{a}$ & -6.25 \\
\hline $\begin{array}{l}\text { L.S.D: } \\
p \leq 0.05\end{array}$ & 2.66 & & 3.71 & & 0.06 & \\
\hline
\end{tabular}

Values of the same letter in the same column do not differ significantly and vice versa.

2- Effect of Jojoba oil, lavender oil, and mixture of both oils on organs weight (g) of hypercholesterolemic rats:

A- Liver weight (g): Data of Table (2) showed that hypercholesterolemia resulted in an increase of liver weight (\%) may be due to infliction with the disease and inflammations; control (-) rats revealed $-22.03 \%$ less in weight $\%$ than observed for the hypercholesterolemic , both fed on the basal diet. Oils used in experimental diets and their mixture indicated pronounced decreasing of liver weight $(\%)$, percent decrease ranging from $-20.28 \%$ to $-28.11 \%$. The best treatment revealed maximum decreasing of liver weight was observed for Jojoba oil $5 \%$ (group 4).

B- $\quad$ Spleen weight (g): Data of Table (2) illustrated that hypercholesterolemia resulted in an increase of spleen weight $(\%)$ may be caused by infliction with the disease; control (-) rats revealed $-4.34 \%$ less in weight than observed for the hypercholesterolemic rats fed on the basal diet. Oils used in experimental diets and their mixture revealed pronounced decreasing of spleen weight (\%) ranging from $-33.69 \%$ to $-45.65 \%$. The Jojoba oil 5\% (group 4) was the better treatment showed maximum decreasing of spleen weight.

C- Lungs weight (g): Data of Table (2) show that hypercholesterolemia resulted in an increase of lungs weight (\%) may be due to infliction with the disease. Control (-) rats revealed $-18.75 \%$ less in weight than noticed for the hypercholesterolemic rats fed on the basal diet. Oils used in experimental diets and their mixture indicated pronounced decreasing of lungs weight (\%) ranging from $+2.50 \%$ to $-6.25 \%$. The best treatment showed maximum decreasing of lungs weight was noticed for Jojoba oil at $5 \%$ (group4). 
D- Heart weight (g): Data of Table (2) illustrated that hypercholesterolemia resulted in an increase of heart weight (\%) may be caused by inflammation of the disease. Control (-) rats revealed $-7.36 \%$ less in spleen weight than observed for the hypercholesterolemic rats fed on the basal diet. Oils used in experimental diets and their mixture revealed pronounced decreasing of heart weight (\%) ranging from $-28.42 \%$ to $-40.00 \%$ compared to control (+) group. Accordingly the better treatment showed maximum decreasing of heart weight was observed for lavender oil 5\% (group 6).

E- Kidneys weight (g): Data of Table (2) showed that hypercholesterolemia resulted in an increase of kidneys weight (\%) may be due to infliction of the disease. Control (-) rats revealed $-14.88 \%$ less than noticed for the hypercholesterolemic rats fed on the basal diet. Oils used in experimental diets \& their mixture indicate pronounced decreasing of kidneys weight (\%) ranging from $-12.50 \%$ to $-22.62 \%$. The best treatment showed maximum decreasing of kidneys weight was noticed for Jojoba oil 5\% (group4).

Table (2): Effect of Jojoba oil, lavender oil and mixture of both oils on relative organs weight $(\mathrm{g})$ of hypercholesterolemic rats.

\begin{tabular}{|c|c|c|c|c|c|}
\hline \multirow{2}{*}{ Groups Parameter } & \multicolumn{5}{|c|}{ Relative organs weight (g/100 g. B.Wt.) } \\
\hline & Liver & Spleen & Lungs & Heart & Kidneys \\
\hline Control-ve (G1) & $5.38 \pm 0.03 \mathbf{b}$ & $0.88 \pm 0.02 \mathbf{a}$ & $1.30 \pm 0.02 \mathbf{a}$ & $0.88 \pm 0.03 \mathbf{a}$ & $1.43 \pm 0.02 \mathbf{b}$ \\
\hline $\begin{array}{l}\text { \% Change of } \\
\text { Control (+) group }\end{array}$ & -22.03 & -4.34 & -18.75 & -7.36 & -14.88 \\
\hline Control+ve (G2) & $6.90 \pm 0.10 \mathbf{a}$ & $0.92 \pm 0.02 \mathbf{a}$ & $1.60 \pm 0.20 \mathrm{a}$ & $0.95 \pm 0.02 \mathbf{a}$ & $1.68 \pm 0.03 \mathrm{a}$ \\
\hline $\begin{array}{l}\text { \% Change of } \\
\text { Control (+) group }\end{array}$ & 0.00 & 0.00 & 0.00 & 0.00 & -0.00 \\
\hline $\begin{array}{l}\text { Jojoba oil (2.5\%) } \\
\text { (G3) }\end{array}$ & $5.02 \pm 0.02 \mathbf{b}$ & $0.54 \pm 0.03 \mathbf{b}$ & $1.61 \pm 0.02 \mathbf{a}$ & $0.64 \pm 0.02 \mathbf{b}$ & $1.36 \pm 0.02 \mathbf{b}$ \\
\hline $\begin{array}{l}\text { \% Change of } \\
\text { Control (+) group }\end{array}$ & -27.24 & -41.30 & +0.63 & -32.63 & -19.04 \\
\hline $\begin{array}{l}\text { Jojoba oil (5\%) } \\
\text { (G4) }\end{array}$ & $4.96 \pm 1.00 \mathbf{b}$ & $0.50 \pm 0.10 \mathbf{c}$ & $1.50 \pm 0.50 \mathbf{a}$ & $0.60 \pm 0.10 \mathbf{b}$ & $1.30 \pm 0.30 \mathbf{b}$ \\
\hline $\begin{array}{l}\text { \% Change of } \\
\text { Control (+) group }\end{array}$ & -28.11 & -45.65 & -6.25 & -36.84 & -22.62 \\
\hline $\begin{array}{l}\text { Lavender oil (2.5\%) } \\
\text { (G5) }\end{array}$ & $5.84 \pm 1.61 \mathbf{a}$ & $0.61 \pm 0.03 \mathbf{b}$ & $1.64 \pm 0.04 \mathbf{a}$ & $0.68 \pm 0.04 \mathbf{b}$ & $1.47 \pm 0.03 \mathbf{b}$ \\
\hline $\begin{array}{l}\% \text { Change of } \\
\text { Control (+) group }\end{array}$ & -20.57 & -33.69 & +2.50 & -28.42 & -12.50 \\
\hline $\begin{array}{l}\text { Lavender oil (5\%) } \\
\text { (G6) }\end{array}$ & $5.50 \pm .0 .50 \mathbf{b}$ & $0.58 \pm 0.03 \mathbf{b}$ & $1.60 \pm 0.65 \mathbf{a}$ & $0.57 \pm 0.02 \mathbf{c}$ & $1.40 \pm 0.05 \mathbf{a b}$ \\
\hline $\begin{array}{l}\text { \% Change of } \\
\text { Control }(+) \text { group }\end{array}$ & -20.28 & -36.95 & 0.00 & -40.00 & -16.66 \\
\hline $\begin{array}{l}\text { Mixture of both oils } \\
2.5 \% \text { (G7) }\end{array}$ & $5.30 \pm 0.30 \mathbf{b}$ & $0.58 \pm 0.03 \mathbf{b}$ & $1.61 \pm 0.01 \mathbf{a}$ & $0.68 \pm 0.04 \mathbf{b}$ & $1.41 \pm 0.01 \mathbf{a b}$ \\
\hline $\begin{array}{l}\text { \% Change of } \\
\text { Control (+) group }\end{array}$ & -23.19 & -36.95 & +0.63 & -28.42 & -16.07 \\
\hline L.S.D: $\quad p \leq 0.05$ & 1.31 & 0.08 & 0.56 & 0.08 & 0.20 \\
\hline
\end{tabular}

Values of the same letter in the same column do not differ significantly and vice versa. 
3 - Effect of Jojoba oil, lavender oil and mixture of both oils at $2.5 \%$ on serum glucose of hypercholesterolemic rats:

Data of Table (3) illustrated that hypercholesterolemia resulted in an increase of serum glucose (mgldl), may be caused by inflicting of the disease. Control (-) rats revealed $-11.26 \%$ less than observed for the hypercholesterolemic rats fed on the basal diet. Oils used in experimental diets \& their mixture revealed pronounced decreasing of serum glucose ranging from $30.42 \%$ to $-43.67 \%$. Accordingly, the best treatment showed maximum decreasing of serum glucose was observed for Jojoba oil 5\%; (group4).

Table (3): Jojoba oil, lavender oil at 2.5 -5 \% and mixture of both oils on serum glucose of hypercholesterolemic rats.

\begin{tabular}{|c|c|c|}
\hline Groups Parameter & Glucose (mg/dl) & $\begin{array}{c}\text { \% Change of Control } \\
(+) \text { group }\end{array}$ \\
\hline Control-ve (G1) & $115.80 \pm 2.31 \mathbf{b}$ & -11.26 \\
\hline Control+ve (G2) & $130.50 \pm 1.50 \mathbf{a}$ & 0.00 \\
\hline Jojoba oil (2.5\%) (G3) & $84.00 \pm 2.00 \mathrm{~d}$ & -35.63 \\
\hline Jojoba oil (5\%) (G4) & $73.50 \pm 1.50 \mathrm{e}$ & -43.67 \\
\hline Lavender oil (2.5\%) (G5) & $90.80 \pm 2.20 \mathrm{c}$ & -30.42 \\
\hline Lavender oil (5\%) (G6) & $86.50 \pm 0.50 \mathrm{~d}$ & -33.71 \\
\hline Mixture of both oils 2.5\% (G7) & $88.20 \pm 0.20 \mathrm{~cd}$ & -32.41 \\
\hline L.S.D: $\quad p \leq 0.05$ & 2.88 & \\
\hline
\end{tabular}

Values of the same letter in the same column do not differ significantly and vice versa.

4 - Effect of Jojoba oil, lavender oil and mixture of both oils on serum total cholesterol (T.C.) , triglycerides (T.G), high density lipoprotein cholesterol (H. D.L.c), Low density lipoprotein cholesterol (L.D.L-c), very low density lipoprotein cholesterol (V.L.D.L-c) and atherogenic index (A.I) of hypercholesterlemic rats:

A-Total cholesterol (T.C.) mg/dl: Data of Table (4) revealed that hypercholesterolemia resulted in marked increase of serum total cholesterol (mgldl), may be caused by inflicting of the disease. Control (-) rats indicated $63.26 \%$ less than observed for the hypercholesterolemic rats fed on the basal diet. Oils used in experimental diets and their mixture showed pronounced decreasing of serum TC ranging from $-37.96 \%$ to $-51.02 \%$. Therefore, numerically the best treatment showed significantly maximum decreasing of serum TC was observed for Jojoba oil 5\% (group 4) .

B- Serum Triglycerides (T. G) mg/dl: Data of Table (4) illustrated that hypercholesterolemia resulted in an increase of serum triglycerides (mgldl), may be caused by inflicting of the disease. Control (-) rats revealed $-72.41 \%$ less than observed for the hypercholesterolemic rats fed on the basal diet. Oils used in experimental diets and their mixture revealed pronounced decreasing of serum TG ranging from $-55.86 \%$ to $-66.21 \%$. The best treatment showed significantly maximum decreasing of serum TG was observed for Jojoba oil 2.5\% (group3). 
Table (4): Effect of Jojoba oil, lavender oil and mixture of both oils on serum total cholesterol (T.C.), triglycerides (T.G), of hypercholesterolemic rats.

\begin{tabular}{|c|c|c|c|c|}
\hline Groups & $\begin{array}{c}\text { Total cholesterol } \\
(\mathrm{mg} / \mathrm{dl}) \\
\text { Mean } \pm \text { SD }\end{array}$ & $\begin{array}{c}\% \text { Change of } \\
\text { Control }(+) \\
\text { group }\end{array}$ & $\begin{array}{c}\text { Triglycerides } \\
(\mathrm{mg} / \mathrm{dl}) \\
\text { Mean } \pm \text { SD }\end{array}$ & $\begin{array}{c}\% \text { Change of } \\
\text { Control }(+) \\
\text { group }\end{array}$ \\
\hline Control-ve (G1) & $90.00 \pm 2.64 \mathbf{f}$ & -63.26 & $40.00 \pm 2.00 \mathrm{e}$ & -72.41 \\
\hline Control+ve (G2) & $245.00 \pm 2.00 \mathbf{a}$ & 0.00 & $145.00 \pm 2.64 \mathbf{a}$ & 0.00 \\
\hline Jojoba oil (2.5\%) (G3) & $135.00 \pm 2.00 \mathrm{~d}$ & -44.89 & $49.00 \pm 1.00 \mathrm{~d}$ & -66.21 \\
\hline \begin{tabular}{|ll} 
Jojoba oil (5\%) & (G4) \\
\end{tabular} & $120.00 \pm 2.00 \mathbf{e}$ & -51.02 & $55.00 \pm 2.00 \mathbf{c}$ & -62.06 \\
\hline $\begin{array}{l}\text { Lavender oil (2.5\%) } \\
\text { (G5) }\end{array}$ & $152.00 \pm 2.00 \mathbf{b}$ & -37.96 & $60.00 \pm 3.00 \mathrm{bc}$ & -58.62 \\
\hline $\begin{array}{l}\text { Lavender oil (5\%) } \\
\text { (G6) }\end{array}$ & $136.00 \pm 2.64 \mathbf{d}$ & -44.89 & $64.00 \pm 4.00 \mathbf{b}$ & -55.86 \\
\hline $\begin{array}{l}\text { Mixture of both oils } \\
2.5 \% \text { (G7) }\end{array}$ & $144.00 \pm 4.00 \mathrm{c}$ & -41.22 & $55.00 \pm 2.00 \mathbf{c}$ & -62.06 \\
\hline L.S.D: $\quad \mathbf{p} \leq \mathbf{0 . 0 5}$ & 4.49 & & 4.44 & \\
\hline
\end{tabular}

Values of the same letter in the same column do not differ significantly and vice versa.

C- Serum high density lipoprotein cholesterol (H.D.L-c) mg/dl: Data of Table (5) revealed that hypercholesterolemia resulted in the decrease of serum HDL (mgldl), may be caused by inflicting with the disease. Control (-) rats indicated $+68.88 \%$ more than observed for the hypercholesterolemic rats fed on the basal diet. Oils used in experimental diets and their mixture showed pronounced increasing of serum HDLc ranging from $+31.11 \%$ to $+57.77 \%$. The best treatment showed maximum increasing of serum HDLc was observed for Jojoba oil 5\% (group4).

D- Serum low density lipoprotein cholesterol (L.D.L-c) mg/dl: Data of Table (5) illustrated that hypercholesterolemia resulted in an increase of serum LDLc (mgldl), may be caused by inflicting of the disease. Control (-) rats indicated $96.49 \%$ less than observed for the hypercholesterolemic rats fed on the basal diet. Oils used in experimental diets and their mixture showed pronounced decreasing of serum LDLc ranging from $-52.63 \%$ to $-77.77 \%$. Therefore, the best treatment indicating maximum decreasing of serum LDLc was observed for Jojoba oil at 5\% (group 4). 
Table (5): Effect of Jojoba oil, lavender oil and mixture of both oils on high density lipoprotein cholesterol (H. D.L.c) and Low density lipoprotein cholesterol (L.D.L-c) of hypercholesterlemic rats.

\begin{tabular}{|c|c|c|c|c|}
\hline \multirow[b]{2}{*}{ Groups } & \multicolumn{4}{|c|}{ Lipoprotein fractions (mg/dl) } \\
\hline & $\begin{array}{c}\text { HDLc. }(\mathrm{mg} / \mathrm{dl}) \\
\text { Mean } \pm \text { SD }\end{array}$ & $\begin{array}{c}\% \text { Change of } \\
\text { Control (+) } \\
\text { group } \\
\end{array}$ & $\begin{array}{c}\text { LDLc. } \\
(\mathrm{mg} / \mathrm{dl}) \\
\text { Mean } \pm \text { SD }\end{array}$ & $\begin{array}{l}\% \text { Change } \\
\text { of Control } \\
\text { (+) group } \\
\end{array}$ \\
\hline Control-ve (G1) & $76.00 \pm 2.64 \mathbf{a}$ & +68.88 & $6.00 \pm 1.00 \mathrm{f}$ & -96.49 \\
\hline Control+ve (G2) & $45.00 \pm 3.00 \mathrm{e}$ & 0.00 & $171.00 \pm 3.60 \mathbf{a}$ & 0.00 \\
\hline Jojoba oil (2.5\%) (G3) & $66.00 \pm 2.00 \mathrm{c}$ & +46.66 & $59.20 \pm 0.20 \mathrm{~d}$ & -65.38 \\
\hline Jojoba oil (5\%) (G4) & $71.00 \pm 2.00 \mathbf{b}$ & +57.77 & $38.00 \pm 2.00 \mathrm{e}$ & -77.77 \\
\hline Lavender oil (2.5\%) (G5) & $59.00 \pm 2.00 \mathrm{~d}$ & +31.11 & $81.00 \pm 1.00 \mathrm{~b}$ & -52.63 \\
\hline Lavender oil (5\%) (G6) & $62.00 \pm 2.00 \mathrm{~cd}$ & +37.77 & $61.20 \pm 0.20 \mathrm{~d}$ & -64.21 \\
\hline $\begin{array}{l}\text { Mixture of both oils } \\
2.5 \% \text { (G7) }\end{array}$ & $63.00 \pm 2.00 \mathbf{c d}$ & +40.00 & $70.00 \pm 3.00 \mathrm{c}$ & -59.06 \\
\hline L.S.D: $\quad p \leq 0.05$ & 3.97 & & 3.51 & \\
\hline
\end{tabular}

Values of the same letter in the same column do not differ significantly and vice versa.

E- Serum very low density lipoprotein cholesterol (V.L.D.L- c) mg/dl: Data of Table (6) indicated that hypercholesterolemia resulted in the increase of serum and VLDLc (mgldl), may be caused by inflicting of the disease. Control (-) rats indicated $-72.41 \%$ less than observed for the hypercholesterolemic rats fed on the basal diet. Oils used in experimental diets \& their mixture revealed pronounced decreasing of serum VLDLc ranging from $-55.86 \%$ to $-66.21 \%$. The best treatment showed numerically maximum decreasing of serum VLDLc was noticed for Jojoba oil at $2.5 \%$ (group 3).

F- Serum atherogenic index (AI) ratio: Data of Table (6) illustrated that hypercholesterolemia resulted in an increase of serum atherogenic index (mgldl), may be caused by inflicting of the disease. Control (-) rats indicated $-95.94 \%$ less than observed for the hypercholesterolemic rats fed on the basal diet. Oils used in experimental diets and their mixture showed pronounced decreasing of serum (AI) ranging from $-64.41 \%$ to $-84.46 \%$. Therefore, the best treatment indicating maximum decreasing of serum (AI) was observed for Jojoba oil at $5 \%$ (group 4). 
Table (6): Effect of Jojoba oil, lavender oil and mixture of both oils on very low density lipoprotein cholesterol (V.L.D.L-c) and atherogenic index (A.I) of hypercholesterlemic rats.

\begin{tabular}{|c|c|c|c|c|}
\hline \multirow[b]{2}{*}{ Groups } & \multicolumn{4}{|c|}{ Lipoprotein fractions (mg/dl) } \\
\hline & $\begin{array}{c}\text { VLDLc. } \\
(\mathrm{mg} / \mathrm{dl}) \\
\text { Mean } \pm \text { SD }\end{array}$ & $\begin{array}{c}\text { \% Change of } \\
\text { Control (+) } \\
\text { group }\end{array}$ & $\begin{array}{c}\text { Atherogenic } \\
\text { index (AI) } \\
(\mathrm{mg} / \mathrm{dl}) \\
\text { Mean } \pm \text { SD }\end{array}$ & $\begin{array}{l}\text { \% Change } \\
\text { of Control } \\
\text { (+) group }\end{array}$ \\
\hline Control-ve (G1) & $8.00 \pm 1.00 \mathrm{~b}$ & -72.41 & $0.18 \pm 0.03 \mathbf{g}$ & -95.94 \\
\hline Control+ve (G2) & $29.00 \pm 2.64 \mathbf{a}$ & 0.00 & $4.44 \pm 0.04 \mathbf{a}$ & 0.00 \\
\hline Jojoba oil (2.5\%) (G3) & $9.80 \pm 1.00 \mathbf{b}$ & -66.21 & $1.05 \pm 0.05 \mathrm{e}$ & -76.35 \\
\hline Jojoba oil (5\%) (G4) & $11.00 \pm 2.64 \mathbf{b}$ & -62.06 & $0.69 \pm 0.02 \mathbf{f}$ & -84.46 \\
\hline Lavender oil (2.5\%) (G5) & $12.00 \pm 2.00 \mathrm{~b}$ & -58.62 & $1.58 \pm 0.04 \mathbf{b}$ & -64.41 \\
\hline Lavender oil (5\%) (G6) & $12.80 \pm 0.40 \mathbf{b}$ & -55.86 & $1.19 \pm 0.03 \mathrm{~d}$ & -73.19 \\
\hline $\begin{array}{l}\text { Mixture of both oils } \\
2.5 \% \text { (G7) }\end{array}$ & $11.00 \pm 2.00 \mathrm{~b}$ & -62.06 & $1.29 \pm 0.03 \mathbf{c}$ & -70.94 \\
\hline L.S.D: $\quad p \leq 0.05$ & 3.25 & & 0.06 & \\
\hline
\end{tabular}

Values of the same letter in the same column do not differ significantly and vice versa.

5 - Effect of Jojoba oil, lavender oil and mixture of both oils on liver function of hypercholesterolemic rats

A- Serum glutamic oxaloacetate transaminase (GOT) or (AST) enzyme (U/L): Data of Table (7) illustrated that hypercholesterolemia resulted in an increase of serum (AST) (U/L), may be caused by inflicting of the disease. Control (-) rats indicated - $18.52 \%$ less than observed for the hypercholesterolemic rats fed on the basal diet. Oils used in experimental diets and their mixture showed pronounced decreasing of serum (AST) (U/L) ranging from $-7.41 \%$ to $-27.41 \%$. The best treatment indicating maximum decreasing of serum (AST) (U/L) was observed for lavender oil at 5\% (group 6).

B- Serum glutamic pyruvate transaminase (GPT) or (ALT) enzyme (U/L): Data of Table (7) revealed hypercholesterolemia that resulted in an increase of serum (ALT) (U/L) caused by inflicting of the disease. Control (-) rats showed$22.50 \%$ less than observed for the hypercholesterolemic rats fed on the basal diet. Oils used in experimental diets and their mixture showed pronounced decreasing of serum (ALT) (U/L) ranging from $-12.50 \%$ to $-30.00 \%$. The best treatment indicating maximum decreasing of serum (ALT) (U/L) was observed for lavender oil 5\% (group 6). 
Table (7): Jojoba oil, lavender oil and mixture of both oils as effecting on AST and ALT of hypercholesterolemic rats.

\begin{tabular}{|c|c|c|c|c|}
\hline Groups Parameter & $\begin{array}{l}\operatorname{AST}(\mathbf{U} / \mathbf{L})^{*} \\
\operatorname{Mean} \pm \text { SD }\end{array}$ & $\begin{array}{l}\% \text { Change } \\
\text { of Control } \\
\text { (+) group }\end{array}$ & $\begin{array}{c}\text { ALT } \\
(\mathbf{U} / \mathbf{L}) \\
\text { Mean } \pm \\
\text { SD }\end{array}$ & $\begin{array}{c}\% \text { Change of } \\
\text { Control (+) } \\
\text { group }\end{array}$ \\
\hline Control-ve (G1) & $110.00 \pm 2.65 \mathrm{~d}$ & -18.52 & $31.00 \pm 2.00 \mathbf{b c}$ & -22.50 \\
\hline Control+ve (G2) & $135.00 \pm 2.00 \mathbf{a}$ & 0.00 & $40.00 \pm 3.00 \mathbf{a}$ & 0.00 \\
\hline $\begin{array}{l}\text { Jojoba oil (2.5\%) } \\
\text { (G3) }\end{array}$ & $118.00 \pm 2.64 \mathbf{c}$ & -12.59 & $35.00 \pm 2.64 \mathbf{b}$ & -12.50 \\
\hline $\begin{array}{l}\text { Jojoba oil (5\%) } \\
\text { (G4) }\end{array}$ & $102.00 \pm 2.00 \mathbf{e}$ & -24.44 & $30.00 \pm 2.00 \mathbf{c}$ & -25.00 \\
\hline $\begin{array}{l}\text { Lavender oil (2.5\%) } \\
\text { (G5) }\end{array}$ & $125.00 \pm 2.00 \mathbf{b}$ & -7.41 & $32.00 \pm 2.00 \mathbf{b c}$ & -20.00 \\
\hline $\begin{array}{l}\text { Lavender oil (5\%) } \\
\text { (G6) }\end{array}$ & $98.00 \pm 2.64 \mathbf{e}$ & -27.41 & $28.00 \pm 2.00 \mathbf{c}$ & -30.00 \\
\hline $\begin{array}{l}\text { Mixture of both oils } \\
2.5 \% \text { (G7) }\end{array}$ & $123.00 \pm 2.00 \mathbf{b}$ & -8.88 & $33.00 \pm 2.64 \mathbf{b c}$ & -17.50 \\
\hline L.S.D: $p \leq 0.05$ & 4.03 & & 4.13 & \\
\hline
\end{tabular}

Values of the same letter in the same column do not differ significantly and vice versa.

C- Serum alkaline phosphatase (ALP) enzyme (U/L): Data of Table (8) illustrated that hypercholesterolemia resulted in an increase of serum (ALP) (U/L), may be caused by inflicting of the disease. Control (-) rats indicated $12.20 \%$ less than observed for the hypercholesterolemic rats fed on the basal diet. Oils used in experimental diets and their mixture showed pronounced decreasing of serum (ALP) (U/L) ranging from $-4.76 \%$ to $-13.69 \%$. The best treatment indicating maximum decreasing of serum (ALP) (U/L) was observed for Jojoba oil at $5 \%$ (group 4).

D- Serum AST/ALP (U/L): Data of Table (8) illustrated that hypercholesterolemia resulted in a decrease of serum AST /ALP (U/L), may be caused by inflicting of the disease. Control (-) rats indicated $+5.03 \%$ more than observed for the hypercholesterolemic rats fed on the basal diet. Oils used in experimental diets and their mixture showed pronounced decreasing of serum AST /ALP (U/L) ranging from $+15.68 \%$ to $-0.29 \%$. The best treatment indicating maximum decreasing of serum AST/ALP (U/L) was observed for Jojoba oil at $2.5 \%$ (group 3). 
Table (8): Jojoba oil, lavender oil and mixture of both oils as effecting on

ALP and AST /ALP of hypercholesterolemic rats.

\begin{tabular}{|c|c|c|c|c|}
\hline Groups Rarameter & $\begin{array}{l}\operatorname{ALP}(\mathbf{U} / \mathbf{L})^{*} \\
\text { Mean } \pm \text { SD }\end{array}$ & $\begin{array}{l}\text { \% Change } \\
\text { of Control } \\
\text { (+) group }\end{array}$ & $\begin{array}{c}\text { AST /ALT } \\
(\text { U/L })^{*} \\
\text { Mean } \pm \\
\text { SD }\end{array}$ & $\begin{array}{c}\% \text { Change of } \\
\text { Control (+) } \\
\text { group }\end{array}$ \\
\hline Control-ve (G1) & $295.00 \pm 2.65 \mathrm{~d}$ & -12.20 & $3.55 \pm 0.02 \mathbf{a}$ & +5.03 \\
\hline Control+ve (G2) & $336.00 \pm 2.00 \mathbf{a}$ & 0.00 & $3.38 \pm 0.68 \mathbf{a}$ & 0.00 \\
\hline $\begin{array}{l}\text { Jojoba oil (2.5\%) } \\
\text { (G3) }\end{array}$ & $310.00 \pm 3.00 \mathrm{c}$ & -7.74 & $3.37 \pm 0.99 \mathbf{a}$ & -0.29 \\
\hline $\begin{array}{l}\text { Jojoba oil (5\%) } \\
\text { (G4) }\end{array}$ & $290.00 \pm 3.00 \mathrm{~d}$ & -13.69 & $3.40 \pm 0.40 \mathbf{a}$ & +0.59 \\
\hline $\begin{array}{l}\text { Lavender oil (2.5\%) } \\
\text { (G5) }\end{array}$ & $320.00 \pm 3.61 \mathbf{b}$ & -4.76 & $3.91 \pm 1.00 \mathbf{a}$ & +15.68 \\
\hline $\begin{array}{l}\begin{array}{l}\text { Lavender oil (5\%) } \\
\text { (G6) }\end{array} \\
\end{array}$ & $309.00 \pm 3.61 \mathbf{c}$ & -8.03 & $3.50 \pm 0.50 \mathbf{a}$ & +3.55 \\
\hline $\begin{array}{l}\text { Mixture of both oils } \\
2.5 \% \text { (G7) }\end{array}$ & $320.00 \pm 2.00 \mathbf{b}$ & -4.76 & $3.73 \pm 0.04 \mathbf{a}$ & -10.36 \\
\hline L.S.D: $p \leq 0.05$ & 5.08 & & 1.12 & \\
\hline
\end{tabular}

Values of the same letter in the same column do not differ significantly and vice versa.

6 - Effect of Jojoba oil, lavender oil and mixture of both oils on glutathione peroxidase (GPX), super oxidize dismutase (SOD) and catalase (CAT) of hypercholesterolemic rats:

A - Serum Glutathione peroxides (GPX): Data of Table (9) revealed that hypercholesterolemia resulted in the decrease of serum GPX, may be caused by inflicting with the disease. Control (-) rats indicated $+148.14 \%$ more than observed for the hypercholesterolemic rats fed on the basal diet. Oils used in experimental diets and their mixture showed pronounced increasing of serum GPX ranging from $+5.45 \%$ to $+151.36 \%$. The best treatment showed maximum increasing of serum GPX was observed for Jojoba oil 5\% (group4).

B - Serum super oxidize (SOD): Data of Table (9) revealed that hypercholesterolemia resulted in the decrease of serum SOD, may be caused by inflicting with the disease. Control (-) rats indicated $+30.33 \%$ more than observed for the hypercholesterolemic rats fed on the basal diet . Oils used in experimental diets \& their mixture showed pronounced increasing of serum SOD ranging from $+7.86 \%$ to $+29.31 \%$. The best treatment showed maximum increasing of serum SOD was observed for Jojoba oil 5\% (group4).

C-Serum catalase (CAT): Data of Table (9) revealed that hypercholesterolemia resulted in the decrease of serum catalase may be caused by inflicting with the disease. Control (-) rats indicated $+178.87 \%$ more than observed for the hypercholesterolemic rats fed on the basal diet. Oils used in experimental diets and their mixture showed pronounced increasing of serum catalase ranging from 
$+101.69 \%$ to $+162.36 \%$. The best treatment showed maximum increasing of serum catalase was observed for Jojoba oil 5\% (group4).

Table (9): Jojoba oil, lavender oil at and mixture of both oils as effecting on glutathione peroxidase (GPX), super oxidize dismutase (SOD) and catalase (CAT) of hypercholesterolemic rats.

\begin{tabular}{|c|c|c|c|c|c|c|}
\hline oups & $\begin{array}{l}\text { Glutathione } \\
\text { peroxidase } \\
\text { Mean } \pm \text { SD }\end{array}$ & $\begin{array}{c}\% \\
\text { Change } \\
\text { of } \\
\text { Control } \\
(+) \\
\text { group }\end{array}$ & \begin{tabular}{|c|} 
Super \\
oxidize \\
dismutase \\
Mean \pm SD
\end{tabular} & \begin{tabular}{|c|}
$\%$ \\
Change \\
of \\
Control \\
$(+)$ \\
group
\end{tabular} & $\begin{array}{c}\text { Catalase } \\
\text { Mean } \pm \\
\text { SD }\end{array}$ & $\begin{array}{c}\% \\
\text { Change } \\
\text { of } \\
\text { Control } \\
(+) \\
\text { group }\end{array}$ \\
\hline $\begin{array}{l}\text { ontrol-ve } \\
\text { 1) }\end{array}$ & $\begin{array}{r}40.05 \pm \\
\mathbf{a}\end{array}$ & +148.14 & $\begin{array}{c}48.42 \pm 2.67 \\
\mathbf{a}\end{array}$ & +30.33 & $\begin{array}{c}83.94 \pm 2.67 \\
\text { a }\end{array}$ & +178.87 \\
\hline $\begin{array}{l}\text { ntrol+ve } \\
\text { 2) }\end{array}$ & 16 & 0.00 & $\begin{array}{c}37.15 \pm 0.78 \\
\text { c }\end{array}$ & 0.00 & $\begin{array}{c}30.10 \pm 0.85 \\
\mathbf{f}\end{array}$ & 0.00 \\
\hline ail & b & +138.54 & $0 \mathbf{b}$ & \begin{tabular}{|l|}
+17.09 \\
\end{tabular} & $\begin{array}{c}73.21 \pm 1.69 \\
\mathbf{c}\end{array}$ & +143.22 \\
\hline Jojoba oil (5\%) & 40.57 & +151.36 & $\begin{array}{c}48.04 \pm 1.94 \\
\mathbf{a}\end{array}$ & +29.31 & $\begin{array}{c}78.97 \pm 1.95 \\
\text { b }\end{array}$ & +162.36 \\
\hline il & 17.0 & +5.45 & $\begin{array}{c}40.07 \pm 1.89 \\
\text { c }\end{array}$ & +7.86 & $\begin{array}{c}60.71 \pm 1.45 \\
\mathrm{e}\end{array}$ & +101.69 \\
\hline $\begin{array}{l}\text { avende } \\
5 \%)(\mathrm{G}(\end{array}$ & 21.18 & +31.23 & $44.15 \pm 1.77 b$ & +18.84 & $\begin{array}{c}68.06 \pm 0.91 \\
\text { d }\end{array}$ & +126.11 \\
\hline $\begin{array}{l}\text { Mixture of } \\
\text { ooth oils } 2.5 \% \\
\text { G7) }\end{array}$ & $27.76 \pm 1.37 \mathbf{c}$ & +31.23 & $41.80 \pm 1.31 b$ & +12.52 & $\begin{array}{c}65.00 \pm 2.00 \\
\text { d }\end{array}$ & +115.95 \\
\hline S.D: & 2.01 & & 3.39 & & 3.07 & \\
\hline
\end{tabular}

Values of the same letter in the same column do not differ significantly and vice versa.

7- Effect of Jojoba oil, lavender oil and mixture of both oils level on kidney function of hypercholesterolemic rats:

A- Serum urea (mg/dl): Data of Table (10) show that hypercholesterolemia resulted in an increase of serum urea $(\mathrm{mg} / \mathrm{dl})$, may be caused by inflicting the disease. Control (-) rats indicated $-30.84 \%$ less than observed for the hypercholesterolemic rats fed on the basal diet. Oils used in experimental diets and their mixture showed pronounced decreasing of serum urea $(\mathrm{mg} / \mathrm{dl})$ ranging from $-9.74 \%$ to $-27.27 \%$. The best treatment revealed maximum decreasing of serum urea $(\mathrm{mg} / \mathrm{dl})$ was observed for Jojoba oil at 5\% (group 4)and 2.5mixture of both oils(G7).

B- Serum creatinine (mg/dl): Data of Table (10) illustrated that hypercholesterolemia resulted in an increase of serum creatinine $(\mathrm{mg} / \mathrm{dl})$, may be caused by inflicting the disease. Control (-) rats indicated $-11.63 \%$ less than observed for the hypercholesterolemic rats fed on the basal diet. Oils used in 
experimental diets and their mixture showed pronounced decreasing of serum creatinine $(\mathrm{mg} / \mathrm{dl})$ ranging from $-6.97 \%$ to $-30.23 \%$. The best treatment indicating maximum decreasing of serum creatinine $(\mathrm{mg} / \mathrm{dl})$ was observed for Jojoba oil at $5 \%$ (group 4).

C- Serum uric acid (U.A.) (mg/dl): Data of Table (10) illustrated that hypercholesterolemia resulted in an increase of serum uric acid $(\mathrm{mg} / \mathrm{dl})$, may be caused by inflicting the disease. Control (-) rats indicated $-26.47 \%$ less than observed for the rats fed on the basal diet. Oils used in experimental diets and their mixture as $2.5 \%$ and $5 \%$ showed pronounced decreasing of serum uric acid $(\mathrm{mg} / \mathrm{dl})$ ranging from $-29.41 \%$ to $-52.94 \%$. The best treatment indicating maximum decreasing of serum uric acid (mg/dl) was Jojoba oil at 5\% (group 4).

Table (10): ): Jojoba oil, lavender oil and mixture of both oils as effecting on kidney function of hypercholesterolemic rats.

\begin{tabular}{|c|c|c|c|c|c|c|}
\hline Parameter & $\begin{array}{c}\text { Urea } \\
(\mathrm{mg} / \mathrm{dl}) \\
\text { Mean } \pm \\
\text { SD }\end{array}$ & $\begin{array}{c}\% \\
\text { Chang } \\
\text { e of } \\
\text { Contro } \\
1(+) \\
\text { group } \\
\end{array}$ & $\begin{array}{c}\text { Creatinine } \\
(\mathrm{mg} / \mathrm{dl}) \\
\text { Mean } \pm \\
\text { SD }\end{array}$ & $\begin{array}{c}\% \\
\text { Change } \\
\text { of } \\
\text { Control } \\
(+) \\
\text { group } \\
\end{array}$ & $\begin{array}{c}\text { Uric acid } \\
(\mathrm{mg} / \mathrm{dl}) \\
\text { Mean } \pm \\
\text { SD }\end{array}$ & $\begin{array}{c}\% \\
\text { Change } \\
\text { of } \\
\text { Control } \\
\text { (+) group }\end{array}$ \\
\hline $\begin{array}{l}\text { Control-ve } \\
\text { (G1) }\end{array}$ & $\begin{array}{c}21.30 \pm 1.57 \\
\text { c } \\
\end{array}$ & -30.84 & $\begin{array}{c}0.38 \pm 0.02 \\
\text { abc } \\
\end{array}$ & -11.63 & $2.50 \pm 0.26 \mathbf{b}$ & -26.47 \\
\hline $\begin{array}{l}\text { Control+ve } \\
\text { (G2) }\end{array}$ & $\begin{array}{c}30.80 \pm 1.31 \\
\mathbf{a} \\
\end{array}$ & 0.00 & $0.43 \pm 0.03 \mathbf{a}$ & 0.00 & $3.40 \pm 0.20 \mathbf{a}$ & 0.00 \\
\hline \begin{tabular}{|l|} 
Jojoba oil \\
$(2.5 \%)(G 3)$
\end{tabular} & $\begin{array}{c}27.50 \pm 0.50 \\
\text { b } \\
\end{array}$ & -10.71 & $\begin{array}{c}0.34 \pm 0.02 \\
\text { bc }\end{array}$ & -20.93 & $2.00 \pm 0.50 \mathrm{~b}$ & -41.17 \\
\hline $\begin{array}{l}\text { Jojoba oil } \\
(5 \%) \quad(G 4)\end{array}$ & $\begin{array}{c}22.40 \pm 0.40 \\
\text { c }\end{array}$ & -27.27 & $0.30 \pm 0.05 \mathrm{c}$ & -30.23 & $1.60 \pm 0.40 \mathrm{~b}$ & -52.94 \\
\hline $\begin{array}{l}\text { Lavender oil } \\
(2.5 \%)(\mathbf{G 5}) \\
\end{array}$ & \begin{tabular}{|c}
$27.80 \pm 1.59$ \\
b \\
\end{tabular} & -9.74 & $\begin{array}{c}0.40 \pm 0.04 \\
\text { ab } \\
\end{array}$ & -6.97 & $2.40 \pm 0.40 \mathbf{b}$ & -29.41 \\
\hline $\begin{array}{l}\text { Lavender oil } \\
(5 \%)(\mathrm{G6})\end{array}$ & $\begin{array}{c}25.40 \pm 0.40 \\
\text { b }\end{array}$ & -17.53 & $\begin{array}{c}0.36 \pm 0.04 \\
\text { abc }\end{array}$ & -16.28 & $2.20 \pm 0.20 \mathbf{b}$ & -35.29 \\
\hline $\begin{array}{l}\text { Mixture of } \\
\text { both oils } \\
2.5 \% \text { (G7) }\end{array}$ & $\begin{array}{c}26.00 \pm 2.00 \\
\mathbf{b}\end{array}$ & -17.53 & $\begin{array}{c}0.37 \pm 0.02 \\
\text { abc }\end{array}$ & -13.95 & $2.30 \pm 0.30 \mathbf{b}$ & -32.35 \\
\hline $\begin{array}{l}\text { L.S.D: } \\
\text { p } \leq 0.05\end{array}$ & 2.22 & & 0.05 & & 0.59 & \\
\hline
\end{tabular}

Values of the same letter in the same column do not differ significantly and vice versa.

8- Effect of jojoba oil, lavender oil and mixture of both oils level on total protein, albumin, globulin and albumin/globulin ratio of hypercholesterolemic rats.

A - Serum total protein (T.P.): Data of Table (11) revealed that hypercholesterolemia resulted in the decrease of serum T.P., may be caused by inflicting with the disease. Control (-) rats indicated $+21.87 \%$ more than 
observed for the hypercholesterolemic rats fed on the basal diet . Oils used in experimental diets and their mixture showed pronounced increasing of serum T.P. ranging from $-3.12 \%$ to $+12.50 \%$. The best treatment showed maximum increasing of serum T.P. was observed for Jojoba oil 5\% (group4).

B-Serum albumin: Data of Table (11) revealed that hypercholesterolemia resulted in the decrease of serum albumin may be caused by inflicting with the disease. Control (-) rats indicated $+73.33 \%$ more than observed for the hypercholesterolemic rats fed on the basal diet. Oils used in experimental diets and their mixture showed pronounced increasing of serum albumin ranging from $+60.00 \%$ to $+106.66 \%$. The best treatment showed maximum increasing of serum albumin was observed for Jojoba oil 5\% (group4).

Table (11): ): Jojoba oil, lavender oil and mixture of both oils as effecting on total protein and albumin of ratio of hypercholesterolemic rats.

\begin{tabular}{|c|c|c|c|c|}
\hline Groups & $\begin{array}{c}\text { Total } \\
\operatorname{protein}(\mathrm{mg} / \mathrm{dl}) \\
\text { Mean } \pm \text { SD }\end{array}$ & $\begin{array}{c}\text { \% Change of } \\
\text { Control (+) } \\
\text { group }\end{array}$ & $\begin{array}{c}\text { Albumin } \\
(\mathrm{mg} / \mathrm{dl}) \\
\text { Mean } \pm \text { SD }\end{array}$ & $\begin{array}{c}\text { \% Change of } \\
\text { Control }(+) \\
\text { group }\end{array}$ \\
\hline Control-ve (G1) & $7.80 \pm 0.10 \mathbf{a}$ & +21.87 & $5.20 \pm 0.20 \mathbf{b}$ & +73.33 \\
\hline Control+ve (G2) & $6.40 \pm 0.40 \mathbf{c}$ & 0.00 & $3.00 \pm 0.50 \mathrm{c}$ & 0.00 \\
\hline \begin{tabular}{|l} 
Jojoba oil (2.5\%) \\
(G3)
\end{tabular} & $7.10 \pm 0.10 \mathrm{~b}$ & +10.93 & $5.90 \pm 0.26 \mathbf{a}$ & +96.66 \\
\hline $\begin{array}{l}\text { Jojoba oil (5\%) } \\
(\text { G4) }\end{array}$ & $7.20 \pm 0.20 \mathbf{b}$ & +12.50 & $6.20 \pm 0.20 \mathbf{a}$ & +106.66 \\
\hline \begin{tabular}{|l} 
Lavender oil \\
$(2.5 \%)($ G5) \\
\end{tabular} & $6.20 \pm 0.20 \mathbf{c}$ & -3.12 & $4.80 \pm 0.26 \mathbf{b}$ & +60.00 \\
\hline $\begin{array}{l}\text { Lavender oil (5\%) } \\
(\text { G6) }\end{array}$ & $6.30 \pm 0.30 \mathbf{c}$ & 1.56 & $5.00 \pm 0.50 \mathbf{b}$ & +66.00 \\
\hline $\begin{array}{l}\text { Mixture of both } \\
\text { oils 2.5\% (G7) } \\
\end{array}$ & $6.70 \pm 0.20$ bc & +4.68 & $5.40 \pm 0.40 \mathbf{b}$ & +80.00 \\
\hline L.S.D: $\quad$ p $\leq 0.05$ & 0.41 & & 0.62 & \\
\hline
\end{tabular}

Values of the same letter in the same column do not differ significantly and vice versa.

C- Serum globulin (mg/dl): Data of Table (12) illustrated that hypercholesterolemia resulted in an increase of serum globulin (mg/dl), may be caused by inflicting the disease. Control (-) rats indicated $-23.53 \%$ less than observed for the rats fed on the basal diet. Oils used in experimental diets and their mixture as $2.5 \%$ and $5 \%$ showed pronounced decreasing of serum Globulin (mg/dl)ranging from $-58.82 \%$ to $-70.58 \%$. The best treatment indicating maximum decreasing of serum Globulin (mg/dl) was Jojoba oil at 5\% (group 4).

D- Serum albumin/globulin ratio: Data of Table (12) illustrated that hypercholesterolemia resulted in decrease of serum Albumin/Globulin ratio, may be caused by inflicting the disease. Control (-) rats indicated $+122.22 \%$ less than observed for the rats fed on the basal diet. Oils used in experimental diets and 
their mixture as $2.5 \%$ and $5 \%$ showed pronounced decreasing of serum Albumin/Globulin ratio ranging from $+277.77 \%$ to $+588.88 \%$. Significantly the best treatment indicating maximum decreasing of serum albumin/Globulin ratio was Jojoba oil at 5\% (group 4).

Table (12): ): Jojoba oil, lavender oil and mixture of both oils as effecting on globulin and albumin/globulin ratio of hypercholesterolemic rats.

\begin{tabular}{|c|c|c|c|c|}
\hline Groups & $\begin{array}{c}\text { Globulin } \\
(\mathrm{mg} / \mathrm{dl}) \\
\text { Mean } \pm \text { SD }\end{array}$ & $\begin{array}{c}\% \text { Change } \\
\text { of Control } \\
(+) \text { group }\end{array}$ & $\begin{array}{c}\text { Albumin/Globulin } \\
\text { ratio } \\
\text { Mean } \pm \text { SD }\end{array}$ & $\begin{array}{c}\% \text { Change of } \\
\text { Control }(+) \\
\text { group }\end{array}$ \\
\hline Control-ve (G1) & $2.60 \pm 0.26 \mathbf{b}$ & -23.53 & $2.00 \pm 0.26 \mathbf{e}$ & +122.22 \\
\hline Control+ve (G2) & $3.40 \pm 0.20 \mathrm{a}$ & 0.00 & $0.90 \pm 0.10 \mathbf{f}$ & 0.00 \\
\hline $\begin{array}{l}\text { Jojoba oil (2.5\%) } \\
\text { (G3) }\end{array}$ & $1.20 \pm 0.20 \mathrm{c}$ & -64.70 & $4.90 \pm 0.26 \mathbf{b}$ & +444.44 \\
\hline $\begin{array}{l}\text { Jojoba oil (5\%) } \\
(\text { G4) }\end{array}$ & $1.00 \pm 0.10 \mathbf{c}$ & -70.58 & $6.20 \pm 0.20 \mathbf{a}$ & +588.88 \\
\hline $\begin{array}{l}\text { Lavender oil } \\
(2.5 \%)(G 5) \\
\end{array}$ & $1.40 \pm 0.20 \mathbf{c}$ & -58.82 & $3.40 \pm 0.40 \mathrm{~d}$ & +277.77 \\
\hline $\begin{array}{l}\text { Lavender oil } \\
(5 \%)(\mathbf{G 6}) \\
\end{array}$ & $1.30 \pm 0.30 \mathbf{c}$ & -61.76 & $3.90 \pm 0.36 \mathbf{c}$ & +333.33 \\
\hline $\begin{array}{l}\text { Mixture of both } \\
\text { oils } 2.5 \% \text { (G7) }\end{array}$ & $1.30 \pm 0.30 \mathbf{c}$ & -61.76 & $4.20 \pm 0.20 \mathbf{c}$ & +366.66 \\
\hline L.S.D: $\quad p \leq 0.05$ & 0.41 & & 0.47 & \\
\hline
\end{tabular}

Values of the same letter in the same column do not differ significantly and vice versa.

9- Effect of Jojoba oil, lavender oil and mixture of both oils on total bilirubin, indirect bilirubin and direct bilirubin of hypercholesterolemic rats:

A- Serum total bilirubin (mg/dl): Data of Table (13) show that hypercholesterolemia resulted in an increase of serum total bilirubin $(\mathrm{mg} / \mathrm{dl})$ may be caused by inflicting the disease. Control (-) rats indicated $-17.31 \%$ less than observed for the hypercholesterolemic rats fed on the basal diet. Oils used in experimental diets and their mixture showed pronounced decreasing of serum total bilirubin $(\mathrm{mg} / \mathrm{dl})$ ranging from $+3.84 \%$ to $-23.07 \%$. The best treatment revealed maximum decreasing of serum total bilirubin $(\mathrm{mg} / \mathrm{dl})$ was observed for Jojoba oil at 5\% (group 4).

B- Serum indirect bilirubin (mg/dl): Data of Table (13) illustrated that there was non significant difference between $(C+v e)$ group and $(C-v e)$ group. It could be observed that there was no significant difference between all treatment groups.

C- Serum direct bilirubin (mg/dl): Data of Table (13) illustrated that hypercholesterolemia resulted in an increase of serum Direct Bilirubin $(\mathrm{mg} / \mathrm{dl})$ may be caused by inflicting the disease. Control (-) rats indicated $-22.50 \%$ less 
(العدد الثانى)

than observed for the rats fed on the basal diet. Oils used in experimental diets and their mixture as $2.5 \%$ and $5 \%$ showed pronounced decreasing of serum direct bilirubin $(\mathrm{mg} / \mathrm{dl})$ ranging from $+2.50 \%$ to $-32.50 \%$. The best treatment indicating maximum decreasing of serum Direct Bilirubin $(\mathrm{mg} / \mathrm{dl})$ was Jojoba oil at $5 \%$ (group 4).

Table (13): Jojoba oil, lavender oil and mixture of both oils as effecting on total bilirubin, indirect bilirubin and direct bilirubin of hypercholesterolemic rats.

\begin{tabular}{|c|c|c|c|c|c|c|}
\hline $\begin{array}{l}\text { Parame } \\
\text { roups }\end{array}$ & $\begin{array}{c}\text { Total } \\
\text { Bilirubin } \\
(\mathrm{mg} / \mathrm{dl}) \\
\text { Mean } \pm \mathrm{SD}\end{array}$ & \begin{tabular}{|c}
$\%$ \\
Change \\
of \\
Control \\
$(+)$ \\
group \\
\end{tabular} & $\begin{array}{c}\text { Indirect } \\
\text { Bilirubin } \\
(\mathrm{mg} / \mathrm{dl}) \\
\text { Mean } \pm \text { SD }\end{array}$ & $\begin{array}{c}\% \\
\text { Change } \\
\text { of } \\
\text { Control } \\
(+) \\
\text { group }\end{array}$ & $\begin{array}{c}\text { Direct } \\
\text { Bilirubin } \\
\text { (mg/dl) } \\
\text { Mean } \pm \\
\text { SD }\end{array}$ & $\begin{array}{c}\% \\
\text { Change } \\
\text { of } \\
\text { Control } \\
\text { (+) group }\end{array}$ \\
\hline $\begin{array}{l}\text { ontrol-ve } \\
\text { G1) }\end{array}$ & 3 & -17.31 & $0.12 \pm 0.03 \mathbf{a}$ & 0.00 & $\begin{array}{c}0.31 \pm 0.02 \\
\text { bc }\end{array}$ & -22.50 \\
\hline $\begin{array}{l}\text { Control+ve } \\
\text { (G2) }\end{array}$ & 0. & 0.00 & $0.12 \pm 0.01 \mathbf{a}$ & 0.00 & $\begin{array}{c}0.40 \pm 0.03 \\
\mathbf{a}\end{array}$ & 0.00 \\
\hline $\begin{array}{l}\text { Jojoba oil } \\
(2.5 \%)(G 3)\end{array}$ & $\begin{array}{c}0.44 \pm 0.04 \\
\text { bc }\end{array}$ & -15.38 & $\mathbf{a}$ & +8.33 & $\begin{array}{c}0.31 \pm 0.04 \\
\text { bc }\end{array}$ & -22.50 \\
\hline \begin{tabular}{|l|} 
Jojoba oil \\
$(5 \%)$ (G4)
\end{tabular} & 0.4 & -23.07 & $.02 \mathrm{a}$ & +8.33 & $\begin{array}{c}0.27 \pm 0.02 \\
\mathbf{c}\end{array}$ & -32.50 \\
\hline $\begin{array}{l}\text { Lavender oil } \\
(\mathbf{2 . 5 \%}) \text { (G5) }\end{array}$ & $0.54 \pm$ & +3.84 & $02 \mathbf{a}$ & +8.33 & $\begin{array}{c}0.41 \pm 0.01 \\
\mathbf{a}\end{array}$ & +2.50 \\
\hline $\begin{array}{l}\text { Lavender oil } \\
(5 \%) \text { (G6) }\end{array}$ & $\begin{array}{c}0.49 \pm 0.02 \\
\text { ab }\end{array}$ & -5.77 & $0.13 \pm 0.02 \mathbf{a}$ & +8.33 & $\begin{array}{c}0.36 \pm 0.02 \\
\mathbf{a b}\end{array}$ & -10.00 \\
\hline $\begin{array}{l}\text { Mixture of } \\
\text { both oils } \\
2.5 \% \text { (G7) }\end{array}$ & $\begin{array}{c}0.49 \pm 0.02 \\
\mathbf{a b}\end{array}$ & -5.77 & $0.13 \pm 0.02 \mathbf{a}$ & +8.33 & $\begin{array}{c}0.33 \pm 0.02 \\
\mathbf{b}\end{array}$ & -17.50 \\
\hline $\begin{array}{l}\text { S.D: } \quad p \leq \\
05\end{array}$ & 0.05 & & 0.03 & & 0.04 & \\
\hline
\end{tabular}

Values of the same letter in the same column do not differ significantly and vice versa. 
References

Armitage, P. and Berry, G. (1987).Statistical Methods in Medical Research.Blackwell, Oxford, UK, 93-213.

Allian, C.C.(1979).Cholesterol Enzymatic Colorimetric Method. J. of Clin. Chem.,(20): 470.

Barham and Trinder (1972). Quantitative enzymatic colorimetric determination of uric acid in serum, plasma or urine. Analyst, 97:142.

Campbell, J.A.(1963). Methodology of Protein Evaluation. PAG Nutr. Document R.101 Add.37,June,Meeting, Newyork.

Chapman, D.G.; Castilla, R. and Campbell, J.A.(1959). Evaluation of protein in Food . 1.A method for the determination of protein efficiency ratio. Can.J.Biochem . Phosiol.,37:679-686.

Denner, S.S. (2009). Lavandula angustifolia Miller: English lavender. Holist Nurs Pract. ;23(1):57-64.

Faulkner, N.R. and King J.W. (1976). Fundamental of Clinical Chemistry. $2^{\text {nd }}$ Ed.Tietz Editor. Saundres Philadelphia, 994-998.

Fossati, P. and Prencipe, L. (1982). Triglycride Enzymatic Colorimetric Method .J. of Clin. Chem., 28:2077.

Fossati, P.; Prencipe, L. and Berti, G.(1980). Enzymatic colorimetic method for determination of uric acid in serum.Clin.Chim.,26(2):227-273.

Hegsted, D.; Mills, R. and Perkins, E.(1941) Salt mixture.J.Boil.Chem.,138:459.

Henry, R.J.(1974). Clinical Chemistry Principles and Techniques. ${ }^{\text {nd }}$ Ed., Harper and Publishers, Newyork, Philadelphia.

Huang, M.Y.; Liao, M.H.; Wang, Y.K.; Huang, Y.S. and Wen, H.C. (2012). Effect of lavender essential oil on LPS-stimulated inflammation. Am. J. Chin. Med., 40(4):845-59.

IFCC. (1983). Methods for the measurement of catalytic concentration of enzymes, Part 5: IFCC, methodsfor alkaline phosphatase. J.Clin. Chem. Clin Biochem., 21:73 1-748.

Lee, R.and Nieman, D.(1996). Nutritional Assessment.2nd Ed., Mosby, Missouri USA.

Lopez, M.F.(1977). HDL- Cholesterol Colorimetric Method .J. of Clin. Chem., (23):882.

Patton, C.J. and Crouch, S.R. (1977). Enzymatic colorimetric method for determination of urea in serum. Anal.Chem., 49:464-469.

Pazyar, N.; Yaghoobi, R.; Ghassemi, M. R.; Kazerouni, A.; Rafeie, E. and Jamshydian, N. (2013). Jojoba in dermatology: A succinct review. G. Ital. Dermatol. Venereol., 148(6):687-91.

Reeves, P.G.j Nielsen , F.H. and Fahmy , G.C.(1993) . Report of the American Jnstitute of Nutrition Ad Hoe writing Committee on the refrmation of the AIN- 76A - Roden diet . J. Nutr., 123:1939-1551.

Sasannejad, P.; Saeedi, M.; Shoeibi, A.; Gorji, A.; Abbasi, M. and Foroughipour, M. (2012). Lavender essential oil in the treatment of migraine headache: A placebo-controlled clinical trial. Eur Neurol., 67(5):288-91.

Trinder, P. (1969). Glucose enzymatic colorimetric method. J. Ann. Clin. Biochem, (6): 24.

Whitney, E. N. and Rolfes, S. R. (1993) . Understanding Nutrition. 6th.Ed. West Publishing Company. New York, Los Angeles, San Francisco.

Yound, D.S. (1975). Determination of GOT. Clin. Chem., 3:21-25. 